\title{
Mutual Influence between Deficit of Sino-Western Cultural Exchange and English Teaching in China
}

\author{
Long $\mathbf{Y e}^{1,2, a}$ \\ ${ }^{1}$ Macau University of Science and Technology, Macau, 999078, China \\ ${ }^{2}$ Shaoguan University, Shaoguan, 512005, China \\ a bobyeesgu@163.com
}

Keywords: Culture exchange deficit, Sino-western culture exchange, English teaching.

\begin{abstract}
Chinese national culture is in a weak position in the process of communication with the western culture, leading to the phenomenon of cultural communication deficit. The unequal phenomenon of cultural communication between China and foreign countries brings about the fact that English teaching content contains too little Chinese national culture in China, which further deepens the imbalance in cultural exchanges. In view of these problems, this paper puts forward the corresponding solutions to provide some references for the relevant researchers.
\end{abstract}

\section{Introduction}

The process of modernization has accelerated the circulation of spiritual and material products, bringing all ethnic groups into a common global village, and cross-cultural communication has become an indispensable for every country and region [1,2]. However, cultural differences are barriers to cross-cultural communication, and overcoming cultural barriers caused by cultural differences has become a common problem facing the whole world [2]. English, which really deserve the title of global language, could be used as the main bridge for cross-culture communication [3]. English teaching has contributed a lot on intercultural communication in China. Nevertheless, China has a big deficit on the trade of Sino-western culture exchange, and the current English teaching methods on culture is partly responsible for it. With the increasing number of foreign contacts in China, the demand for English talents is becoming more and more important, and the demands are higher and higher. However, this kind of demand has not been fully and effectively satisfied. The demand for a qualified competence on intercultural communication is one of the most challenging and less attention-getting ones. The neglect of infiltrating Chinese national culture into English teaching makes college graduates unable to introduce Chinese culture to foreigners and incompetent of defending Chinese culture when it is misunderstood. Thus, they would always be put in a weak and passive position in intercultural circumstances. So, English teaching in China unvalued the importance of Chinese culture, which is one of the consequences of the deficit of Sino-western culture exchange, and it will intensify the deficit. Therefore, how to embody cultural introduction and effective infiltration in English teaching and to develop students' intercultural communicative competence more effectively is becoming an increasingly urgent task in English teaching. To reduce the cultural exchange deficit between China and foreign countries, we should consider the practicability of teaching when we teach English. Only when we combine our own culture to teach English can we guarantee the position of our culture and optimize the development environment of our higher education.

\section{Hazards of Culture Exchange Deficit}

Weaken Cultural Identity. China's cultural trade deficit has affected China's national cultural identity and posed a threat to China's cultural security. To expand overseas, the western countries, 
under the banner of "transmitting civilization", exported their cultural products to nonwestern countries and implemented unilateral cultural output. With the holding of the cultural discourse and the output of cultural products, they promote its political system, ideology, values and way of life, and they are reshaping the entire world with western cultural values [4]. In the passive acceptance of western culture, people in China, especially the young, tend to ignore or forget Chinese traditional values. Some of them changed their standards of right and wrong with the judgment from western culture, and some of them are in confusion between the value system of western culture and that of Chinese culture. With the rapid spread of western cultural products and culture ideology in China, some young people became obsessed with western festivals such as Christmas and Valentine's Day, however, they know little about traditional festivals or contemptuously disregard them. Chinese national culture is colorful and profound, and it should have its share in the diversity of global culture. The overwhelming blew of western culture in China not only constitute a threat for Chinese national cultural heritage; it is also harmful for the global culture diversity.

Distort China's Image. The cultural deficit between China and foreign countries makes it easy for other countries to misunderstand China. Although the problems in cultural exchanges are not so direct and realistic as war or economic aggression, the cumulative consequences of such deficits are also very thought-provoking. In some countries and regions, the deficit in cultural exchanges has caused losses to the development of the country and the normal life of the people. The rapid rise of China shows a good example for developing countries, but has brought negative impact on China to some extent as well. China exports manufactures to every corner of the world, however, it does little its culture output. Little products are designed under the value of Chinese national culture. People can hardly notice that they are using a Chinese product without look at the "made in China" label. From the cultural aspect, China is still dominated by the west. Because of China's huge trade surplus, for political or economic reasons, governments sometimes might demonize the image of China. Western people lack proper ways to understand oriental culture, which makes western nationalism popular. In China, there are programs about the west when you turn on the TV, but there are very few programs about China in Western countries [5]. This cultural exchange deficit has led people in western countries to misunderstand China and regard China as the biggest threat. Therefore, if we can't stop the deficit of Sino-western culture exchange, it will distort the image of China and those of Chinese people. The distortion of China's image would not only hinder the balanced and equal intercultural communication between China and the west, it may build up barriers for China's international economic and political activities.

Affect English Teaching. The Sino foreign cultural exchange deficit has also affected English Teaching in Colleges and universities. English teachers show a great respect to the textbooks which are fulfilled with western culture, so English teaching is a main source for young people to acquire western culture. Some teachers supplement a lot of western background information besides the textbooks in their teaching simply for pleasing those students fascinated with western culture. English corners always choose western culture related matters as the topics talked about. Tests for language proficiency or achievement tests such as final exams hardly test students' ability on expressing Chinese culture items. In teaching ideas, most of the English teachers agree that if we want to learn English well, we must understand the culture it derived from. Some English teachers believe that the thinking model from Chinese culture has an inhibitory effect on learning English, and they encourage students indulge themselves into western culture and think in British or American ways to get a better understanding of the language. So, they avoid Chinese culture intentionally or unintentionally in their teaching. The result of this kind of teaching is that students would become lest aware of Chinese culture while mastering English, and would be unable to define Chinese culture in English. The incompetence of expressing Chinese culture would greatly impede an equal intercultural communication, and restrict the spread of Chinese culture. Therefore, Chinese national culture is facing huge challenges because of the deficit of Sino-western culture exchange [6]. English, the global language without carrying a real diversified global culture, is intensifying this trend. For the security of Chinese national culture heritage, this trend should be stopped, and we can start it from infiltrating Chinese national culture into English teaching. 


\section{Improve English Teaching to Decrease Culture Exchange Deficit}

Optimize Teaching Curriculum. Because of culture exchange deficit, many college students in China who have excellent grammatical knowledge are too weak on the competence of intercultural communication. Accordingly, English teaching curriculum and extracurricular activities can be optimized by expanding the content of classroom teaching in line with students' learning characteristics and the demand of intercultural communication [6]. Chinese national culture can serve as an important source of extracurricular cultural knowledge. Currently, students are guided by their teachers to read current events, literary classics, and contemporary classic novels to gain culture related knowledge. These materials should include different cultures, especially Chinese national culture. If those materials are not only interesting, but also include the cultural characteristics of various countries, students are more willing to accept them. In this process, students' reading ability can also be improved, and they also have a good understanding of the cultures of different countries. Teachers can infiltrate Chinese culture into listening, reading, writing and oral activities of classroom teaching. Due to the limited time in the classroom, teachers can encourage students get involved into activities such as English corners with topics on Chinese culture or preparing reports or presentations on it. In addition, teachers can also set up world cultural clubs where students could cultivate interest in colorful cultures of both China and the west with a variety of activities. Club can set up cultural themes every week and invites foreign teachers to participate in it, so students can practice and enjoy authentic intercultural communication. Clubs should be student centers and students should be assigned to search for information related to each theme in advance and encouraged to share their knowledge and deliver their viewpoints. To avoid cultural exchange deficit, those themes should equally cover both western and Chinese cultural parts. Schools and Departments can also organize regular lectures on Chinese culture in English or on contrastive analysis between cultures of the west and China. To improve the students' enthusiasm, the lectures can derive activities such as prize competitions and seminars.

Reform Teaching Content. In the context of the Sino-western cultural exchange deficit, English teaching, especially College English teaching, should be more inclusive on cultural connotation. It is impossible to understand a language without knowing the culture it derived from. Many English words are items of its culture or related to it. For second language learners, many communication barriers are caused by the lack of knowledge of culture of English native speaking countries. Therefore, textbooks infiltrated English culture into every stage of English teaching, from primary schools to postgraduate schools. It really helped a lot on improving students' language proficiency, but the neglect of infiltrating Chinese culture into teaching content leads to students' poor performance on expressing Chinese culture related topics which contributes to the intercultural communication deficit when they are communicate with foreigners. Since English is the global language, it has the responsibility to preserve the diversity of global culture besides carrying culture of the west. If other national cultures were ignored in the process of teaching English, learning English would be a process of destroying the diversity of global culture. Developing countries such as China and India possess the most abundant cultural heritages with their long history in the world. It is necessary to put those culture essences into the global culture. However, English are still being taught as the carrier of culture of the west, and it is pessimistic to count on it as the media of building up a rational global culture and spreading it. English should be taught as the carrier of a diversity of global culture and when for non-native speakers, it should be infiltrated with their own national cultures to supplement them into global culture through intercultural communications in English. Therefore, to gain an overall knowledge of global culture, excellent cultures from different nations and regions should be included in the teaching content of English; to reduce the culture exchange deficit and to spread Chinese culture, the teaching content of English in China should be reformed by including more Chinese culture.

Enrich Teaching Methods. With the advance of modern science and technology and the continuous development of modern educational means, the teaching methods and modes of teachers is changing constantly. Teachers can make use of modern multimedia technology to change the 
traditional mode of education. Compared with traditional classroom teaching, the using of internet and a variety of software can better stimulate students' interest and arouse enthusiasm in English learning. New teaching methods supported by internet and software could be very effective on infiltrating culture into English teaching. TV shows, movies, and authentic documentaries on the internet can make cultural infiltration more vibrant and vivid. It is not unusual for English teachers to cultivate students' cultural conciseness with English movies, but hardly any teachers use Chinese movies or videos. Teachers always make assignments on searching information on western culture but rarely do it on Chinese traditional ones. Therefore, currently, the unlimited resource on the internet is a contributor of the culture deficit to some extent. Internet is a double-edged sword, it is how we make use of it makes the difference. Internet could also be used on reducing China's deficit on cultural exchange. There is a large amount of resource on Chinese culture on the internet, and it is easy to search information on Chinese culture in English. If teachers can make full use of these information besides those on western culture both in and outside classroom, students would be cultivated with more overall conciseness of global culture. Teachers can choose lectures, contests, videos, TV shows, movies on the Internet and analyze them in class to help students enhance their national cultural identity. If students are encouraged to watch videos on Chinese culture in English, it would be beneficial for them to improve their intercultural communication competence.

\section{Conclusion}

Under the influence of the Sino-Western cultural exchange deficit, English teaching in China has been greatly affected, which could intensify the deficit in reverse. However, if English are presented as the carrier of global culture and Chinese national culture are infiltrated in the teaching, English teaching could also reduce cultural exchange deficit by optimizing the curriculum, reforming the content of teaching and enriching the teaching methods. Only in this way can we better resist the invasion of cultural exchange deficit and improve the status of Chinese national culture.

\section{References}

[1] Wang Chunxia. Cross-culture Competence and Senior High School Students' Reading Comprehension [D] Liaoning Normal University, 2007.

[2] Zhang Aixia. Cultivation of Cultural Conciseness in Vocational School English Teaching [D] Shandong Normal University, 2008.

[3] Wang Xiaohui. Global English: Lingua Franca or Hegemony? [J]. Journal of Changchun University, 2014, 24(2): 223-225.

[4] Zhang Baiying. Coping Strategies of Trade Deficit of China's Culture Products [J]. Journal of Liaoning Normal University (Social Science Edition), 2015, 38(1): 49-53.

[5] Zhao Zhaoxia. Analysis of Trade Deficit of China's Films and TV Plays in the Cross-cultural Communication [J]. Hebei Academic Journal, 2012, 32(1): 248-250.

[6] Chen Fabao, Zhou Xinhong. On English Hegemony and English-Chinese Cultural Deficit [J]. Journal of Chengdu University (Social Sciences), 2010(1): 115-117. 